\title{
Differential Gene Expression in the Activation and Maturation of Human Monocytes ${ }^{1}$
}

\author{
Ana Rouzaut, Natalia López-Moratalla, and Carlos de Miguel $^{2}$ \\ Departamento de Bioquímica y Biología Molecular, Universidad de Navarra, Apartado Postal 177, \\ 31080 Pamplona, Spain
}

Differential-display or RNA fingerprint was applied to identify genes differentially expressed in monocyte maturation induced by an immunomodulating peptide on human peripheral blood mononuclear cells. Two unknown sequences (06c22 and 06c71) and p21 protein (cyclin dependent kinase inhibitor) were repressed, and three genes activated: Cathepsin D, DRP2 (dihydropirimidinase related protein 2), and gp91phox (91$k D a$ subunit of citochrome $b_{558}$ ). Phenotype of evolving monocytes was analyzed by flow cytometry and mRNA level of identified genes determined by reverse transcription-PCR. The expression pattern of identified genes seemed to correlate with different monocyte subsets, monocyte-derived cells, and expected functional changes. After peptide addition, immature monocytes were initially activated, increasing the expression of CD25, CD69, and HLA-DR markers. This was accompanied by repression of p21 and the two unknown sequences, along with the simultaneous activation of Cathepsin D and DRP2. Later, the differentiation marker CD16 rose, and gp91phox gene expression activated. Further maturation led certain monocytes to express marker CD23 and gp91phox expression to reach a maximum, while Cathepsin D and DR P2 dropped to preactivation levels. Results reflect part of the evolution of immature monocytes toward macrophages and monocyte-derived dendritic cell precursors. $\odot 2000$ Academic Press

Key Words: differential display; human monocytes; cathepsin D; DRP2; gp91phox; p21.

\footnotetext{
${ }^{1}$ This work was supported by Comision Interministerial de Ciencia y Tecnología (CICYT), Spain, Grant SAF 97-0233, and "Fundación Echebano," Spain.

${ }^{2}$ To whom correspondence should be addressed. Fax: 34948 425649. E-mail: cdmiguel@unav.es.
}

Human peripheral blood monocytes $(\mathrm{MO})^{3}$ present a wide heterogeneity (1). The existence of two well defined subsets has been detected by the analysis of surface markers; the majority of MO exhibit strong CD14 expression and are CD16-negative cells $\left(\mathrm{CD} 14^{2+} \mathrm{CD} 16^{-}\right)$, whereas the more mature $\mathrm{CD} 14^{+} \mathrm{CD} 16^{+}$small $\mathrm{MO}$ are less abundant and express high levels of HLA-II molecules, thus possibly becoming potent antigen-presenting cells (APC) (2). MO have been described as precursors of macrophages $(\mathrm{M} \Phi)$ and MO-derived dendritic cells (MDDC), and all cell types retain the ability to convert to the other during the maturation and differentiation process (3). A type of dendritic cell (DC) can arise from the differentiation of $\mathrm{MO}(4)$ or by the proliferation of progenitors of haematopoietic precursors (5) when cultured in the presence of appropriate cytokines. DC play an important role in the control of immunity, and progenitors of two types of DC have been identified, both coexpressing high levels of HLA class II molecules (6): the MDDC, linked to the $\mathrm{MO}$ lineage and involved in the initiation of immune humoral responses, and the Langerhans cell type of DC that might be participating in cellular responses. Changes in the maturation process of MO have been related to the development of several autoimmune disorders $(7,8)$ and DC have been involved in some of them, such as rheumatoid arthritis (9). DCs, possibly the most important APC, have been subjected to studies analyzing specific gene expression with the idea of defining their function (10).

The present work is focused on MO maturation and changes in gene expression associated with that process. We have previously described that certain pep-

\footnotetext{
${ }^{3}$ Abbreviations used: MO, monocyte; APC, antigen presenting cell; $M \Phi$, macrophage; MDDC, monocyte-derived dendritic cells; DC, dendritic cells; PBMC, peripheral blood mononuclear cells; iNOS, inducible NO synthase; RT, reverse transcription; DRP2, dihydropirimidinase-related protein 2; FITC, fluorescein isothiocyanate; PE, phycoerythrin; SSCP, single strand conformation polymorphism; OD, optical density; LPS, lipopolysaccharide; IL, interleukin; IFN, interferon; TNF, tumor necrosis factor; GM-CSF, granulocyte macrophage-colony stimulating factor.
} 
tides, sharing a common structural motif (11-13), induce $\mathrm{MO}$ activation and differentiation when added to peripheral blood mononuclear cells (PBMC). They are known to promote the secretion of monokynes, expression of inducible NO synthase (iNOS), (14) and the appearance of a DNase activity associated with granules on mature MO (15). Synthetic peptide Pa (NVLGAPKKLNESQAV), used in this work, belongs to this group of compounds. It has been shown to interact with the membranes of $\mathrm{MO}$, starting a phosphoinositide signaling pathway (16). F urthermore, repeated stimulation of cultured PBMC from healthy donors with this peptide, induces an evolution of the basal MO population toward subsets similar to those found in fresh blood obtained from patients with autoimmune disorders, such as Graves' disease (17) or multiple sclerosis (18). Taking advantage of this system to induce in vitro differentiation of MO, we applied to these cells the technique called differential display RT-PCR (19) or RNA fingerprint (20), with the idea of identifying genes activated or repressed during the process, thus possibly playing some role in the evolution of MO. At the same time we monitored phenotypical changes in the course of the differentiation, measuring specific surface markers (CD14, CD25, CD69, CD16, and CD23) and HLA-DR expression levels. Data support that there was a consistent relationship between the phenotype of the cells and the expression level of the genes identified by RNA fingerprint, p21 protein (cyclin dependent kinase inhibitor), Cathepsin D, dihydropirimidinase-related protein 2 (DRP2), gp91phox (91-kDa subunit of cytochrome $b_{558}$ ), as well as two other unknown genes.

The development of specific functions requires regulated expression of lineage-specific and ubiquitous genes; therefore, the molecular characterization of activation and maturation of MO will undoubtedly contribute to a better understanding of immunity mechanisms and particularly of how some autoimmune responses are produced.

\section{MATERIALS AND METHODS}

Cell culture. PBMC, obtained from healthy donors (21), were incubated at a concentration of $1 \times 10^{6}$ cells per $\mathrm{ml}$ in RPMI-1640 medium supplemented with $10 \%$ fetal calf serum, $2 \mathrm{mM}$ L-glutamine, penicillin $(100 \mathrm{IU} / \mathrm{ml})$, and streptomycin $(100 \mu \mathrm{g} / \mathrm{ml})$ in a $5 \% \mathrm{CO}_{2}$ humidified (95\%) atmosphere at $37^{\circ} \mathrm{C}$. After $24 \mathrm{~h}$ half of the cells were stimulated by addition of peptide $\mathrm{Pa}$ (30 $\mu \mathrm{g}$ per $10^{6}$ cells) from a solution $(30 \mathrm{mg} / \mathrm{ml})$ in a complete medium. A second addition was performed $24 \mathrm{~h}$ later, and after 5 days of culture nonadherent cells were removed with the supernatant followed by three washes with PBS. Adherent cells consisting mainly of MO were carefully detached by gentle friction, collected by centrifugation, and resuspended directly in a cell lysis solution to extract the RNA to be used in the RNA fingerprint technique.

Differential gene expression in the 5 days of culture was followed by RT-PCR. I solated PBMC were divided into six samples, incubated, and processed to isolate RNA from adherent cells as indicated above. The basal state was determined in cells which had been processed for $4 \mathrm{~h}$. Remaining cells received the first $\mathrm{Pa}$ addition after $24 \mathrm{~h}$, and a second sample was analyzed $4 \mathrm{~h}$ later. The remaining four samples received a second addition of Pa after $48 \mathrm{~h}$, and a third sample was obtained $4 \mathrm{~h}$ later. The last three samples were processed from that moment at 24-h intervals. The phenotypic evolution of $\mathrm{MO}$ was measured by flow cytometry in six parallel samples, where all PBMC were collected and resuspended in PBS containing $0.1 \%$ sodium azide at a density of $10^{7}$ cells $/ \mathrm{ml}$.

Flow cytometry analysis. Aliquots of $5 \times 10^{5}$ cells from each sample were incubated in the dark at $4^{\circ} \mathrm{C}$ for $30 \mathrm{~min}$ with monoclonal antibodies from Becton and Dickinson labeled with FITC or PE: anti-CD14 (Leu-M3)-FITC, anti-CD25 (anti-IL-2R)-PE, anti-CD69 (Leu-23)-PE, anti-CD16 (Leu-11a)-PE, anti-CD23 (Leu-20)-PE, or anti-HLA-DR-PE. Cells were washed twice with cold PBS containing $0.1 \%$ sodium azide, fixed with $1 \%$ paraformaldehyde and stored in the dark at $4^{\circ} \mathrm{C}$ until analysis. Fixed cells (20,000 per sample) were analyzed by two-color flow cytometry with a Becton Dickinson FAC-Scan flow cytometer, and MO were gated according to their light scattering properties. I sotype antibodies of irrelevant specificity were used as negative control. Specific fluorescence intensity represents the difference between the mean channel of the specific antibody and the mean channel of the negative control antibody expressed on a logarithmic scale. The percentage of positive cells was calculated from specific and nonspecific staining.

RNA fingerprint. Total RNA was extracted using the "Total RNA isolation kit" from Biotecx Laboratories, following the instructions, and treated with RNase-free DNase by standard methods (22). For CDNA synthesis, $2 \mu \mathrm{g}$ of RNA were heated at $70^{\circ} \mathrm{C}$ for $3 \mathrm{~min}$, chilled on ice for $2 \mathrm{~min}$, and then incubated at $42^{\circ} \mathrm{C}$ for $1 \mathrm{~h}$ after adding 10 $\mathrm{U}$ of RNAsin, $1 \mathrm{mM}$ deoxynucleoside triphosphates, $200 \mathrm{U}$ of MMLV reverse transcriptase (Gibco BRL), 100 pmol of random hexamers as primers, and $4 \mu \mathrm{l}$ of $5 \times$ reverse transcriptase buffer (125 mM Tris$\mathrm{HCl}, \mathrm{pH} 8.5,15 \mathrm{mM} \mathrm{MgCl}, 325 \mathrm{mM} \mathrm{KCl}$ ) to give a final volume of 20 $\mu \mathrm{l}$. After incubation the reaction was heat inactivated at $75^{\circ} \mathrm{C}$ for 5 min and CDNA frozen at $-20^{\circ} \mathrm{C}$ until use.

All PCR reactions were carried out in 0.2-ml thin wall tubes with an OmniGene thermal cycler (Hybaid). For random PCR reactions we used primers included in the Delta RNA fingerprint kit (Clontech), which shared a common 16-base sequence at the $5^{\prime}$ end (5'ATTAACCCTCACTAAA-) and differed in their last nine $3^{\prime}$ nucleotides: p5 (-GATCTGACTG-3'), p6 (-TGCTGGGTG-3'), p7 (-TGCTGTATG-3'), p8 (-TGGAGCTGG-3'), p9 (-TGTGGCAGG-3'), p10 (-GCACCGTCC-3'). Each reaction was performed in duplicate using two dilutions of each CDNA (1:10 and 1:40) in a final volume of $20 \mu \mathrm{l}$ containing $1 \mu \mathrm{l}$ of the CDNA dilution, $2 \mu \mathrm{l}$ of $10 \times$ PCR buffer (100 $\mathrm{mM}$ Tris- $\mathrm{HCl}, \mathrm{pH}$ 9.0, $500 \mathrm{mM} \mathrm{KCl}, 20 \mathrm{mM} \mathrm{M} \mathrm{gCl}$, 1\% Triton X-100), $50 \mathrm{mM}$ deoxynucleoside triphosphates, $20 \mathrm{pmol}$ of each primer when two were used, or $40 \mathrm{pmol}$ if only one was included, and $1 \mu \mathrm{l}$ of the enzyme mix Advantage Klen Taq Polymerase Mix (Clontech). $\left[\alpha^{-}{ }^{33} \mathrm{P}\right] \mathrm{dATP}(1000-3000 \mathrm{Ci} / \mathrm{mmol})$ was also added $(50 \mathrm{nM})$ as radioactive label. Reactions were started with $5 \mathrm{~min}$ at $95^{\circ} \mathrm{C}$ followed by three low specificity cycles: denaturation $\left(95^{\circ} \mathrm{C}\right.$ for $\left.2 \mathrm{~min}\right)$, annealing $\left(40^{\circ} \mathrm{C}\right.$ for $\left.5 \mathrm{~min}\right)$, and extension $\left(68^{\circ} \mathrm{C}\right.$ for $\left.5 \mathrm{~min}\right)$; and then $22 \mathrm{high}$ specificity cycles: denaturation $\left(95^{\circ} \mathrm{C}\right.$ for $\left.1 \mathrm{~min}\right)$, annealing $\left(60^{\circ} \mathrm{C}\right.$ for $1 \mathrm{~min})$, and extension $\left(68^{\circ} \mathrm{C}\right.$ for $\left.2 \mathrm{~min}\right)$; and finishing with a single incubation at $68^{\circ} \mathrm{C}$ for $7 \mathrm{~min}$.

PCR products were resolved in a regular sequencing gel loading 4 $\mu \mathrm{l}$ of a (1:1) dilution previously denatured by heating at $95^{\circ} \mathrm{C}$ for 2 min. Gels were vacuum dried at $80^{\circ} \mathrm{C}$ onto $3 \mathrm{MM}$ Whatman paper without fixing and exposed to Kodak-X-Omat AR films. Bands selected as being differential were cut off and incubated at $95^{\circ} \mathrm{C}$ for 5 min in $40 \mu$ l of sterile water to elute the DNA, which was transferred to a clean tube and stored frozen at $-20^{\circ} \mathrm{C}$ until use. Each band was analyzed by an SSCP gel after reamplification with the same primers used in the original reaction, as described by Mathieu-Daude et al. 
TABLE I

Specific Primers Used for the Amplification of Each Gene

Gene

Cathepsin D (s)

Cathepsin D (a)

p21 (s)

p21 (a)

gp91phox (s)

gp91phox (a)

DRP2 (s)

DRP2 (a)

$06 \mathrm{c} 22$ (s)

$06 \mathrm{c} 22$ (a)

$06 \mathrm{c} 22$ (s1)

$06 \mathrm{c} 22$ (a1)

$06 c 71$ (s)

$06 c 71$ (a)
Sequence

$\mathrm{T}_{\mathrm{a}}\left({ }^{\circ} \mathrm{C}\right)$

5'-ACAGTGGGCGGGCGAGTG-3'

5'-GGGGGCATCATCAAAAACTT-3'

5'-ACTGAAGGGAAAGGACAAGG-3'

5'-GTAATGAGGAAGAAGGAGAA-3'

5'-GAAACAATAAACAGAGCCTG-3'

5'-AGAAGGCTGTAGGAAAGGAC-3'

5'-AAAAGGAAGGAAGAAAGAAGTC-3'

5'-GTCCATCTCCAAGTGAAAAC-3'

5'-AGCAACCCAACCAGACAGC-3'

5'-TGTAGCCCCAAAGAACCCCCAA-3'

5'-GGAGAGCAGCAACCCAACCAGA-3'

5'-CTTCACAGTGGGATACAAAA-3'

5'-AAAGCAGGGATAAGAACTAC-3'

Product (bp)

63

327

59

347

56

558

60

781

59

61

148

56
338

Note s, sense; a, antisense; $\mathrm{T}_{\mathrm{a}}$, annealing temperature. For $06 \mathrm{c} 22$ two different pairs were used.

(23). The reamplification reaction was performed in $20 \mu \mathrm{l}$ containing $5 \mu \mathrm{l}$ of the eluted DNA, $2 \mu \mathrm{l}$ of $10 \times \mathrm{PCR}$ buffer $(100 \mathrm{mM}$ Tris- $\mathrm{HCl}$, $\mathrm{pH}$ 9.0, $500 \mathrm{mM} \mathrm{KCl}, 20 \mathrm{mM} \mathrm{MgCl}_{2}, 1 \%$ Triton X-100), $200 \mathrm{mM}$ deoxynucleoside triphosphates, $20 \mathrm{pmol}$ of each primer when two were used, or 40 pmol if only one was included, and 1 unit of DNA polymerase from Thermus brockianus "Dynazyme" (Finnzymes). $\left[\alpha-{ }^{33} \mathrm{P}\right] \mathrm{dATP}(1000-3000 \mathrm{Ci} / \mathrm{mmol})$ was also added $(50 \mathrm{nM})$ as radioactive label. Reactions were started at $95^{\circ} \mathrm{C}$ for $5 \mathrm{~min}$ followed by 20 cycles: denaturation $\left(95^{\circ} \mathrm{C}\right.$ for $\left.1 \mathrm{~min}\right)$, annealing $\left(60^{\circ} \mathrm{C}\right.$ for $\left.1 \mathrm{~min}\right)$, and extension $\left(72^{\circ} \mathrm{C}\right.$ for $\left.2 \mathrm{~min}\right)$, ending with a single incubation at $72^{\circ} \mathrm{C}$ for $7 \mathrm{~min}$. Then $10 \mu \mathrm{l}$ of a (1:20) dilution was loaded in an SSCP gel after heating for $2 \mathrm{~min}$ at $95^{\circ} \mathrm{C}$. Gels were dried in a vacuum at $80^{\circ} \mathrm{C}$ onto 3MM Whatman paper and exposed to Kodak-X-Omat AR films. DNA from bands selected as truly differential was eluted and reamplified as described above, except that no isotope was added and each product was extracted from agarose gels for cloning.

Sequencing analysis. PCR products were cloned into pMOSBlue T-vector (Amersham) and sequenced in an automatic laser fluorescent apparatus with the Autoread sequencing kit from Pharmacia. Sequences obtained were compared with those in available databases (EMBL, GeneBank, and DDJ B) using the algorithm BLAST (Basic Local Alignment Search Tool). Search for open reading frames was carried out with the program GeneWorks 2.4 from Intelligenetics.

Expression analysis by RT-PCR. Pairs of specific primers were prepared for each of the genes to be studied with sequences derived from those obtained previously (Table I). RNA was extracted as indicated above and cDNA was also synthesized, as explained above, except that $1 \mu \mathrm{g}$ of RNA was used. Serial dilutions (1:10 to 1:1000) of each CDNA sample were prepared, and PCR carried out from each dilution to select conditions for the amplification to proceed exponentially before the plateau is reached; thus there should be a linear relationship between the quantity of mRNA in the original samples and the final PCR product (24). A fragment of $\beta$-actin mRNA was amplified in each sample, as an internal normalization standard; and exponential phase conditions were also determined for this amplification. All reactions were carried out with $1 \mu$ l of each CDNA dilution and $20 \mathrm{pmol}$ of each specific primer, using the same mixtures as those used in reamplifications made from the SSCP gels. After an initial 5-min period at $95^{\circ} \mathrm{C}, 30 \mathrm{cycles}$ of denaturation $\left(95^{\circ} \mathrm{C}\right.$ for $\left.30 \mathrm{~s}\right)$, annealing ( $\mathrm{T}_{\mathrm{a}}$ for $\left.45 \mathrm{~s}\right)$, and extension $\left(72^{\circ} \mathrm{C}\right.$ for $\left.45 \mathrm{~s}\right)$ were performed, ending with a single incubation at $72^{\circ} \mathrm{C}$ for $5 \mathrm{~min}$. The annealing temperature $\left(T_{a}\right)$ for each reaction (Table I) was determined from the estimated primers $T_{m}$ (25). Reactions were loaded on $1 \%$ agarose gels containing $1 \mu \mathrm{g} / \mathrm{ml}$ ethidium bromide and gels were photographed after electrophoresis. The optical density (OD) of each band was registered by densitometric scanning substracting background from an equivalent empty area of the gel picture. The relative amount of each mRNA was estimated as the OD value obtained in the selected exponential phase conditions divided by the OD value obtained for the $\beta$-actin mRNA in the same sample determined also under exponential phase conditions (24).

\section{RESULTS}

\section{Identification of Differentially Expressed Genes by RNA Fingerprint}

Four PBMC cultures from healthy donors were prepared and RNA extracted from isolated MO of the four samples mixed in an attempt to overcome variability among different individuals. After reverse transcription four random PCR reactions were performed in duplicate from each CDNA preparation. One reaction was carried out with a single primer (p6), while combinations of two primers were used for the others: (p5-p6), (p7-p8), and (p9-p10). After analysis of the corresponding autoradiographs, 36 differential bands were identified, 18 from stimulated and 18 from control cells (Fig. 1A). Since each band from an RNA fingerprint gel frequently contains more than one product, we analyzed all 36 bands by reamplification and SSCP gels according to Mathieu-Daudè et al. (23). This method resolves each band in its components and shows which one is really differentially expressed. Following the criteria of these authors only 12 bands were selected. They gave 20 PCR products, since, as expected, some of the bands rendered more than one in the SSCP gel (Fig. 1B). After cloning, sequencing and search for homologies in the available databases, it 
A
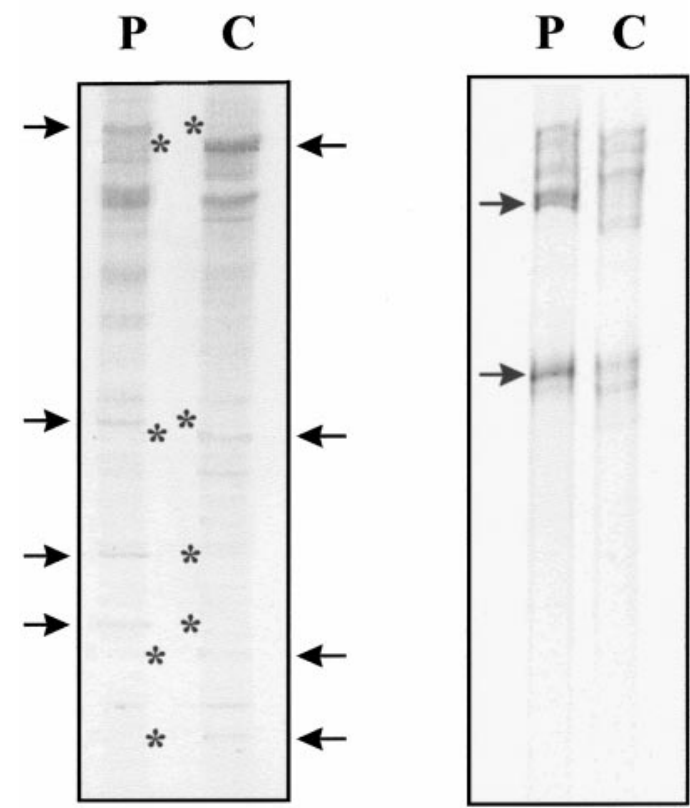

FIG. 1. (A) Example of an RNA fingerprint gel. C, control; $\mathrm{P}, \mathrm{Pa}$ stimulated. Arrows indicate bands that were cut out and reamplified for further SSCP gel analysis. Equivalent regions in the reciprocal adjacent lanes (asterisks) were also cut out and reamplified for comparison in the SSCP gel. (B) Example of an SSCP gel. P, reamplification of a band isolated from a $P$ a stimulated sample; $C$, reamplification of the reciprocal adjacent region from the control sample. Arrows indicate bands cut out and reamplified for cloning and further characterization.

turned out that five clones were identical to known sequences, nine were partially homologous (50-90\%) to sequences present in the databases, and six showed no homology with anything previously known. Clones with unknown sequences not showing an open reading frame were discarded. Clones containing repetitive sequences were also discarded due to the difficulties in confirming the results by RT-PCR. Clones too short to design good specific primers for RT-PCR confirmation were discarded, except when corresponding to a known gene, because, if that was the case, primers could be derived from the published sequence. Six clones were finally selected. Three showed differential expression in the stimulated cells and thus correspond to genes activated by the addition of Pa: Cathepsin D, DRP2, and gp91phox. The other three were differentially expressed in control cells and thus correspond to genes repressed by the addition of Pa: two of them were unknown sequences (referred to as $06 \mathrm{c} 22$ and 06c71), and the third one corresponded to the p21 protein (cyclin dependent kinase inhibitor).
Differential expression was confirmed by RT-PCR on the original cDNA samples with primers specifically designed for each sequence (Table I). A very significant difference in expression was clear for gp91phox and 06c22, while regulation of p21, Cathepsin D, DRP2, and $06 \mathrm{c} 71$ seemed to be more moderate (Fig. 2).

\section{Phenotypic Characterization of Monocyte Subpopulations}

The evolution of MO subpopulations was followed by flow cytometry analysis. PMBC from three different healthy donors were incubated in the presence of peptide $\mathrm{Pa}$ for up to 5 days and samples analyzed every $24 \mathrm{~h}$ as indicated under Materials and Methods. Co-expression of
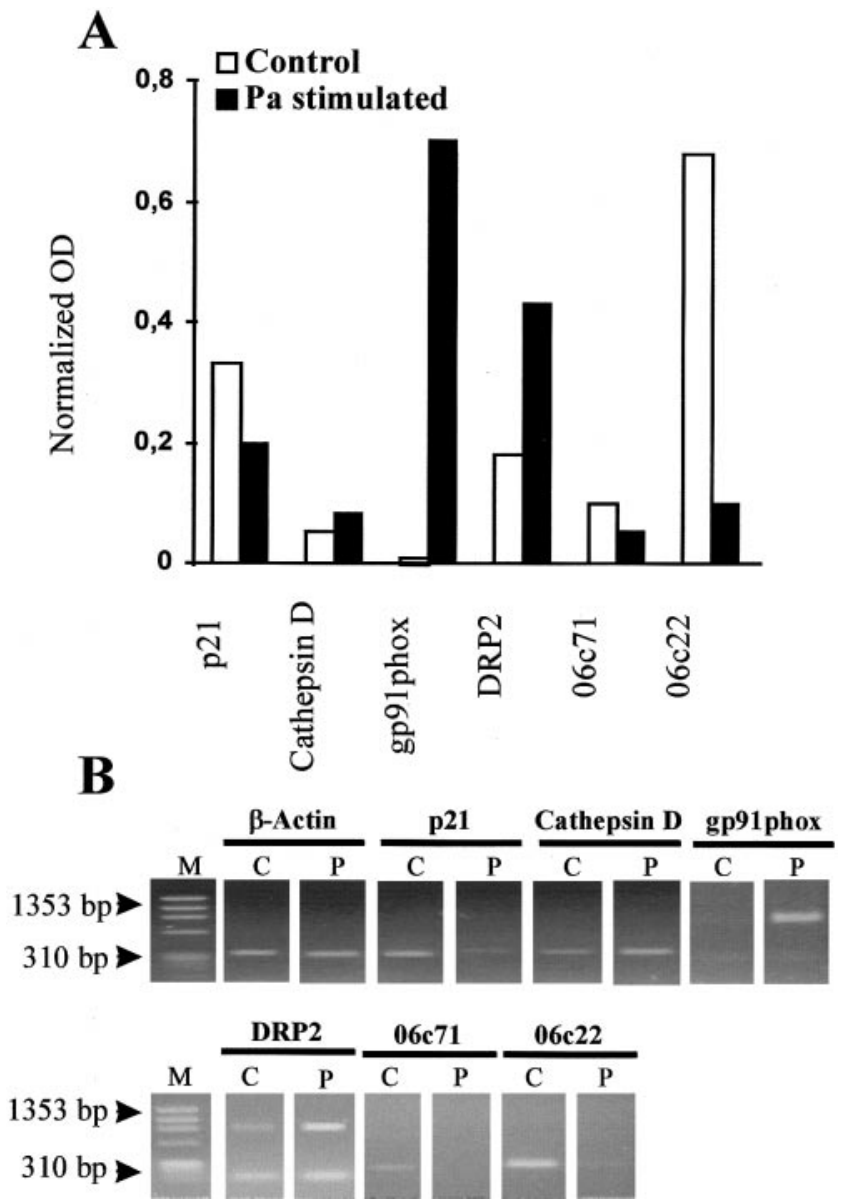

FIG. 2. RT-PCR confirmation of differential gene expression in the original samples. AlI PCR reactions were performed under exponential phase conditions. (A) OD of each band obtained by densitometric analysis and normalized, dividing it by the OD of the $\beta$-actin band in the same sample. (B) Photographs of the different PCR bands obtained. $M$, molecular weight marker ( $\Phi \mathrm{X}-174$ DNA digested with Hael II); C, control; P, Pa stimulated. $\beta$-actin (350 bp), p21 (347 bp), Cathepsin D (327 bp), gp91phox (558 bp), DRP2 (781 bp), 06c71 (338 bp), $06 c 22$ (471 bp). 
CD14 (LPS receptor) together with CD25 (I L-2 receptor), CD69 (signal transducing receptor), CD16 (FcyRIII, lowaffinity IgG receptor), CD23 (FCERIII, Iow-affinity IgE receptor), or HLA-DR was measured using two-color immunofluorescence analysis. The proportion of MO (CD14 expressing cells) coexpressing each different marker with high or low intensity reflected the different subpopulations present. Samples were gathered into four different groups ( $A$ to $D$ ) according to their phenotype, which in turn was indicative of the maturation state of the MO. Figures 3A, 3B, 3C, and 3D summarize the results showing the percentage of the different $\mathrm{MO}$ subsets coexpressing HLA-DR, CD25, CD69, CD16, or CD23 in each group of samples.

The predominant population in the basal nonactivated state A (Fig. 3A) expressed a high level of CD14 and approximately $50 \%$ of $\mathrm{CD}^{2+} \mathrm{MO}$ was $\mathrm{CD} 14^{2+} \mathrm{DR}^{+}$coexpressing a low level of CD25 and CD69. The number of MO coexpressing CD16 was very low and those coexpressing CD23 were almost undetectable. After incubation in the presence of peptide Pa, five samples, obtained on the second or third day of culture (state B), presented a phenotype corresponding to activated MO (Fig. 3B). In this case, the predominant subset was CD14 ${ }^{2+} \mathrm{DR}^{2+}$ and the number of cells expressing a high level of CD25 and CD69 increased, making the most abundant subsets those with phenotypes $\mathrm{CD} 14^{2+} \mathrm{DR}^{2+} \mathrm{CD} 25^{2+}$ and $\mathrm{CD} 14^{2+} \mathrm{DR}^{2+} \mathrm{CD} 69^{2+}$. In contrast, CD16 was present at a low level $\left(\mathrm{CD} 16^{+}\right)$, and only a few CD14 ${ }^{2+}$ cells expressed CD23 at a high level $\left(C D 23^{2+}\right)$. In more advanced states of evolution, induced by peptide $\mathrm{Pa}$ (state $\mathrm{C}$, corresponding to samples taken after 2- 4 days of incubation, and state D, corresponding to samples taken after 3-5 days), an increase in the proportion of small MO, expressing low levels of CD14 and coexpressing CD16, was observed. This $\mathrm{CD}_{14}{ }^{+}$subset as well as the large $\mathrm{CD} 14^{2+} \mathrm{MO}$ coexpressed a high level of HLA-DR. In state $C$, the predominant subset was $\mathrm{CD} 14^{2+} \mathrm{DR}^{2+} \mathrm{CD} 25^{2+} \mathrm{CD} 69^{2+}$ $\mathrm{CD}_{16}{ }^{+/-} \mathrm{CD} 23^{+/-}$. However, in state $\mathrm{D}$ a considerable change in $\mathrm{MO}$ phenotype took place. In that state large mature M $\Phi \mathrm{CD}_{14}{ }^{2+} \mathrm{DR}^{2+} \mathrm{CD} 25^{+} \mathrm{CD} 9^{+} \mathrm{CD} 16^{2+++} \mathrm{CD} 23^{2+/+}$ constituted $70-80 \%$ of all $\mathrm{MO}$, and the remaining $20-$ $30 \%$ were $\mathrm{CD} 14^{+} \mathrm{DR}^{2+} \mathrm{CD} 16^{+}$MDDC precursors, which did not express CD25, CD69, or CD23. In summary, the incubation of PBMC, in the presence of $\mathrm{Pa}$, induced the evolution of immature MO through an activated state toward mature $\mathrm{CD} 14^{2+} \mathrm{DR}^{2+} \mathrm{M} \Phi$ and $\mathrm{CD}^{2+4^{+-}}$ $\mathrm{DR}^{2+}$ MDDC.

Differential Gene Expression during the Evolution of Monocytes

Expression level of the six genes identified by RNA fingerprinting was analyzed by RT-PCR at different stages of the 5-day culture on MO obtained from parallel samples of those used to measure the different surface markers. Figure 3 also shows the results obtained for the four phenotypic groups described above. In basal state A (Fig. 3A), only the cell cycle inhibitor p21 and the unknown genes $06 c 71$ and 06c22 were significantly expressed. These results confirmed the fact that these genes were identified as repressed by $\mathrm{Pa}$ addition in the original RNA fingerprint experiment. In the activated state $B$, these three genes were in fact strongly repressed, while an important induction of Cathepsin D and DRP2 expression (Fig. 3B) also took place. This induction was maintained as the cells reached a more differentiated state $(C)$, where expression of gp91phox was obvious for the first time (Fig. 3C). In the final state D, gp91phox level reached its maximum, being the only gene with relevant expression, since at this stage Cathepsin D and DRP 2 mRNA levels sharply dropped (Fig. 3D). Thus it was possible to see how samples of each group, exhibiting a characteristic phenotype, had in turn a different expression level for each mRNA.

\section{DISCUSSION}

Genes U pregulated in Monocyte Maturation

Cathepsin D is a Iysosomal acid protease present in human MO (26) and its expression increases upon stimulation with LPS, IFN $\gamma$ (27), and differentiating agents such as retinoic acid and calcitriol in HL-60 cells (28). This enzyme has been related to a variety of functions, such as protein degradation (29-31), the generation of antigenic epitopes by proteolysis of more complex molecules (32), and a proteolytic contribution to apoptosis (27). The monocytic enzyme has been involved in the pathologic process of active cryoglobulinemia and associated nephritis via secretion of procathepsin D in tissues (33) and it has been suggested that the inhibition of these proteolytic enzymes in $M \Phi$ may exacerbate immunosuppression in AIDS patients (34). It seems conceivable that after MO activation, genes coding for processing proteases with a wide range of functions, such as Cathepsin D, become activated. In this work we found an activation of the expression of the Cathepsin D gene after stimulation of PBMC cells with peptide $\mathrm{Pa}$. This activation was maintained until the final stages of the differentiation process, when it became downregulated to pretreatment levels (Fig. 3).

DRP2 was initially found in brain and later in other tissues (35), but its function is not well characterized, in spite of being almost identical (98\%) to the collapsin response mediator protein CRMP-62 (36). Collapsin is a member of the semaphorin family implicated in neuronal development, and CRMP-62 stabilizes a complex 


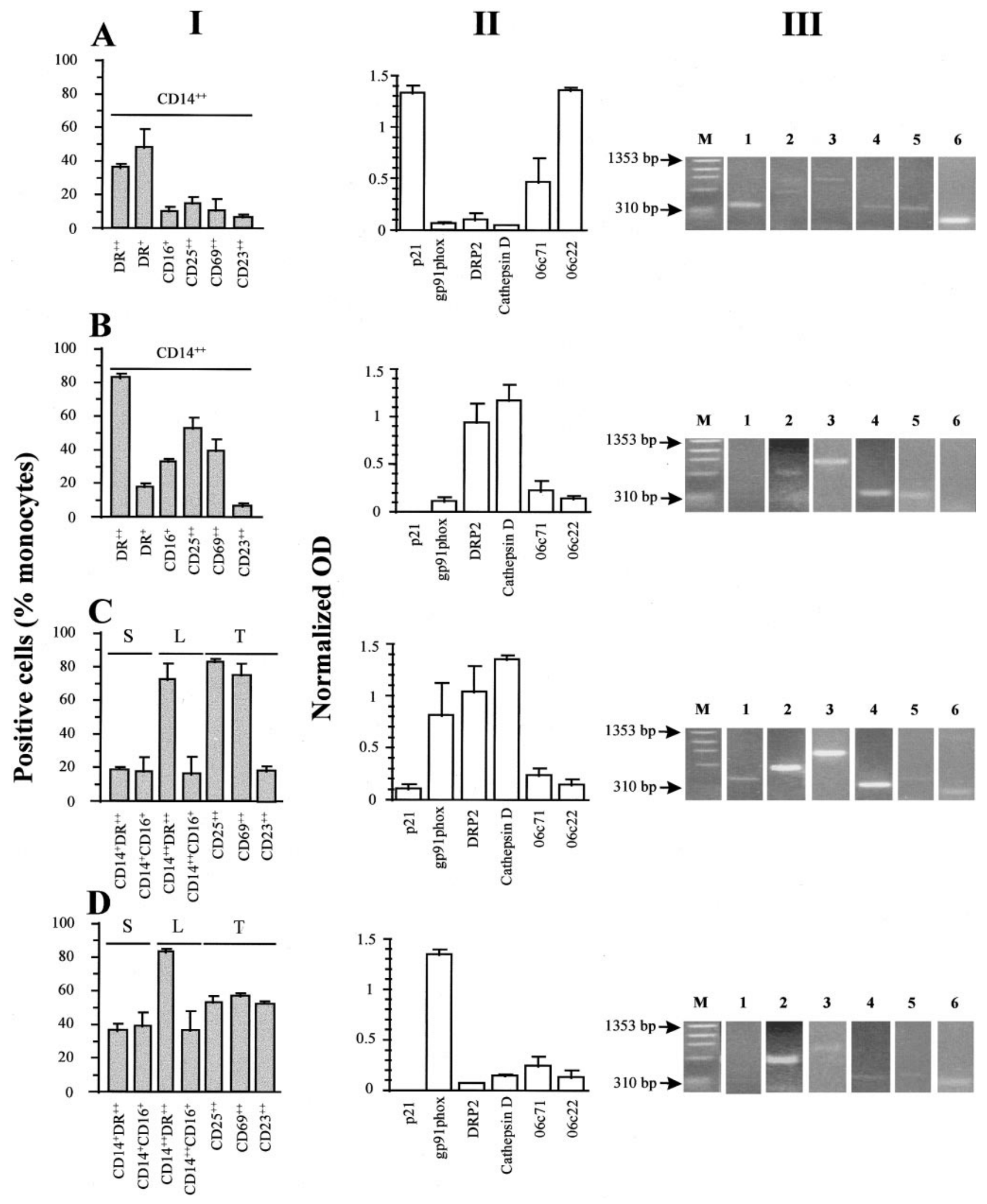


formed by the collapsin receptor and a G protein, upon collapsin binding. That triggers a signaling pathway, which causes reorientation of axonal cone growth (3739). Our results (Fig. 3) show that the DRP2 gene followed a regulation pattern similar to Cathepsin $D$, with a low expression on nonstimulated MO (state A). It also increased after activation with the addition of $\mathrm{Pa}$ (state B) and kept intense values for some time (state C), probably due to a repeated stimulation by a second addition of peptide $\mathrm{Pa}$, all this before falling to the initial level at the end of the process (state D). We think that this is the first report describing the presence of DRP2 in cells of the immune system. If we consider the fact that a molecule called CD100, belonging to the semaphorin receptor family, has been recently identified in lymphocytes (40), it could be suggested that in MO, DRP 2 could act as a mediator along a similar pathway, responding to signals, such as peptide $\mathrm{Pa}$, that induce differentiation.

Protein gp91phox, a subunit of cytochrome $b_{558}$, could be related to the production of reactive oxygen and nitrogen intermediates, and mutations in this gene seem to be associated with $M \Phi$ failure to produce an oxidative response in patients with chronic granulomatosis disease (41). In this work we observed that gp91phox expression was activated in $\mathrm{MO}$ at the end of the maturation process induced by peptide $\mathrm{Pa}$, when cells presented markers associated with cytotoxic properties, such as CD16 and CD23 (Fig. 3). The gp9lphox induction by $\mathrm{Pa}$, as here reported, is consistent with the immunomodulating properties already described for this peptide, such as the release of TNF $\alpha$ and IFN $\gamma$ $(13,42)$, since it has been described that gp91phox expression is induced in cultured MO by stimulation with both cytokines $(43,44)$. The cytotoxic activity (14) and iNOS expression (18) on CD16 positive mature cells induced by $\mathrm{Pa}$ also agree with the enhanced gp91phox expression. Finally, it is interesting to note that $\mathrm{Pa}$ does not induce a release of IL-4 $(13,42)$, since it has been described that human MO cultured with GM-CSF and IL-4 differentiate to DCs without superoxide-generating ability. The low level of cytochrome $b_{558}$, especially the large subunit, brought about by IL-4, might be precisely what is responsible for the low superoxide-generating ability (45). All these observations taken together suggest that gp91phox may be taken as a marker of almost fully differentiated cytotoxic $\mathrm{MO} / \mathrm{M} \Phi$.

\section{Genes Repressed during Monocyte Maturation}

The p21 gene is involved in cell cycle regulation and codes a cyclin dependent kinase inhibitor (CDKI) that blocks the cell cycle in the G1 phase (46). It also inhibits DNA replication, after DNA damage, during the $S$ phase, through its interaction with the proliferative cell nuclear antigen (PCNA) (47). The strong repression of p21 after incubation of cells with $\mathrm{Pa}$ (Fig. 3) indicated the withdrawal of a barrier for cell proliferation, which in turn may be part of the response to the stimulation. The high p21 level in state $A$ also indicated a nonproliferative situation appropriate to a resting nonactivated population. Repression occurred from early activation (state B) and was maintained during the whole process, perhaps as part of the release of the cell cycle necessary to permit cell proliferation. The two unknown sequences $(06 c 71,06 c 22)$ likewise suffered a strong negative regulation in the process; therefore, either their repression was necessary for maturation of $\mathrm{MO}$, or their ceasing off occurred in the course of differentiation. The functional significance of the expression of the two unknown sequences in the basal state $A$ is still unknown. Since they were clearly repressed when cells became activated, their repression must be either an important step in or a consequence of the activation process. Work on the characterization of both genes is now in progress in our laboratory.

In summary, we describe differential expression patterns for several genes in the course of MO maturation in culture. Whether these differences represent a cause or an effect of the maturation process remains an open question, but the variations detected seem consistent with the phenotypic evolution of MO populations. In a recent study we have reported the differential and reciprocal expression of Arginase II and inducible nitric oxide synthase in the same MO maturation process described here, and have shown that there is a correlation between mRNA levels and the different states of maturation (48).

\footnotetext{
FIG. 3. Phenotypic evolution of the $M O$ and RT-PCR analysis of gene expression in the 5 days culture after stimulation with peptide Pa. Samples were divided into four groups (A to D) according to their phenotypic characterization. Graphic I in each panel represents the mean percentages $( \pm S D)$ of the different MO subsets (S, small MO; L, large MO; T, total MO). Graphic II in each panel represent the mean ( \pm SD) of the normalized OD for each band obtained by densitometric analysis. Normalization was done dividing each OD value by the OD of the $\beta$-actin band in the same sample. AlI PCR reactions were performed under exponential phase conditions. Photograph III in each panel shows a representative PCR product of each gene in each group. $\mathrm{M}$, molecular weight marker ( DX-174 DNA digested with Hael II); 1 , p21 (347 bp); 2, gp91phox (558 bp); 3, DRP2 (781 bp); 4, Cathepsin D (327 bp); 5, 06c71 (338 bp); 6, 06c22 (148 bp). $\mathrm{n}=3$ for group A; $\mathrm{n}=5$ for groups $\mathrm{B}, \mathrm{C}$, and D.
} 


\section{ACKNOWLEDGMENTS}

The skillful technical assistance of Mercedes Preciado is gratefully acknowledged. A. Rouzaut was recipient of a fellowship from Gobierno de Navarra, Spain.

\section{REFERENCES}

1. van Furth, R. (1982) I mmunobiology 161, 178-185.

2. Passlick, B., Flieger, D., and Ziegler-Heitbrock, H. W. L. (1989) Blood 74, 2527-2534.

3. Palucka, K. A., Taquet, N., Sanchez-Chapuis, F., and Gluckman, J. C. (1998) J . Immunol. 160, 4587- 4595.

4. Zhou, L. J ., and Tedder T. F. (1996) Proc. Natl. Acad. Sci. USA 93, 2588-2592.

5. Caux, C., Massacrier, C., Vanbervliet, B., Dubois, B., Durand, I., Cella, M., Lanzavecchia, A., and Banchereau, J . (1997) Blood 90, 1458-1470.

6. Banchereau, J ., and Steinman, R. M. (1998) Nature 392, 245252.

7. Porrini, A. M., and Reder, A. T. (1994) Cell. Immunol. 157, 428- 438.

8. J iménez-López, A., Olmos-Martínez, J . M., García-Palomo, J . D., De Dios-Martín, B., Pedraz-García, M. J ., and Lorente-Tol edano, F. (1982) Allergol. Immunopathol. Madrid 10, 353-359.

9. Thomas, R., and Lipsky, P. E. (1996) Arthritis Rheum 39, 183190.

10. Marland, G., Hartgers, F. C., Veltkamp, R., Konigswieser, M. F., Gorman, D., McClanahan, T., Figdor, C. G., and Adema, G. J . (1997) Adv. Exp. Med. Biol. 417, 443- 448.

11. López-Moratalla, N., López-Zabalza, M. J ., Subirá, M. L., Borrás-Cuesta, F., Pérez Mediavilla, L. A., and Santiago, E. (1994) Biochim. Biophys. Acta 1221, 153-158.

12. López-Moratalla, N., Calonge, M. M., López-Zabalza, M. J., Pérez-Mediavilla, L. A., Subirá, M. L., and Santiago, E. (1995) Biochim. Biophys. Acta 1265, 181-188.

13. López-Moratalla, N., Ruiz, E., López-Zabalza, M. J ., and Santiago, E. (1996) Biochim. Biophys. Acta 1317, 183-191.

14. Pérez-Mediavilla, L. A., López-Zabalza, M. J ., Calonge, M., Montuenga, L., López-Moratalla, N., and Santiago, E. (1995) FEBS Lett. 357, 121-124.

15. Pío, R., López-Zabalza, M. J., Rouzaut, A., Santiago, E., and López-Moratalla, N. (1998) Nitric Oxide 2, 165-173.

16. López-Zabalza, M. J ., Martínez-Lausín, S., Bengoechea-Alonso, M. T., López-Moratalla, N., González, A., and Santiago, E. (1997) Arch. Biochem. Biophys. 338, 136-142.

17. González, A., Calleja, A., Santiago, E., de Miguel, C., LópezZabalza, M. J ., and López-Moratalla, N. (1998) Int. J . Mol. Med. 1, 95-103.

18. López-Moratalla, N., González, A., Aymerich, M., López-Zabalza, M. J ., Pío, R., de Castro, P., and Santiago, E. (1997) Nitric Oxide 1, 95-104.

19. Liang, P., and Pardee, A. B. (1992) Science 257, 967-971.

20. Welsh, J., Chada, K., Dalal, S. S., Cheng, R., Ralph, D., and McClelland, M. (1992) Nucleic Acids Res. 20, 4965- 4970.

21. Boyum, A. (1983) Scand. J . I mmunol. 17, 429- 436.

22. Sambrook, J ., Fritsch, E. F., and Maniatis, T. (1989) Molecular Cloning: A Laboratory Manual, Cold Spring Harbor Laboratory Press, Cold Spring Harbor, NY.
23. Mathieu Daude, F., Cheng, R., Welsh, J., and McClelland, M. (1996) Nucleic Acids Res. 24, 1504-1507.

24. Murphy, L. D., Herzog, C. E., Rudick, J. B., Fojo, A. T., and Bates, S. E. (1990) Biochemistry 29, 10351-10356.

25. Itakura, K., Rossi, J . J ., and Wallace, R. B. (1984) Annu. Rev. Biochem. 53, 323-356.

26. Bever, C. T. J r., Morgan, K. D., and Whitaker, J. N. (1989) Inflammation 13, 309-316.

27. Deiss, L. P., Galinka, H., Berissi, H., Cohen, O., and Kimchi, A. (1996) EMBO J . 15, 3861-3870.

28. Atkins, K. B., and Troen, B. R. (1995) Cell Growth Differ. 6, 871- 877.

29. Schwartz, M. K. (1995) Clin. Chim. Acta 237, 67-78.

30. Simon, D. I., Xu, H., and Vaughan, D. E. (1995) Biochim. Biophys. Acta 1268, 143-151.

31. Simon, D. I., Ezratty, A. M., and Loscalzo, J . (1994) Biochemistry 33, 6555- 6563.

32. Chapman, H. A., Riese, R. J ., and Shi, G. P. (1997) Annu. Rev. Physiol. 59, 63- 88.

33. Roccatello, D., Isidoro, C., Mazzucco, G., Mesiti, A., Quattrocchio, G., Amore, A., Molino, A., Coppo, R., Sena, L. M., and Piccoli, G. (1993) Kidney Int. 43, 1150-1155.

34. Bugelski, P. J ., Kaplan, J. M., Hart, T. K., Miller, J ., Laydon, J . T., Lee, J . C., Dreyer, G. B., and Kirsh, R. (1992) AIDS Res. Hum. Retroviruses 8, 1951-1958.

35. Hamajima, N., Matsuda, K., Sakata, S., Tamaki, N., Sasaki, M., and Nonaka, M. (1996) Gene 180, 157-163.

36. Goshima, Y., Nakamura, F., Strittmatter, P., and Strittmatter, S. M. (1995) Nature 376, 509-514.

37. Kolodkin, A. L. (1996) Trends Neurosci. 19, 507-513.

38. Goshima, Y., Kawakami, T., Hori, H., Sugiyama, Y., Takasawa, S., Hashimoto, Y., Kagoshima-Maezono, M., Takenaka, T., Misu, Y., and Strittmatter, S. M. (1997) J . Neurobiol. 33, 316-328.

39. Gaetano, C., Matsuo, T., and Thiele, C. J . (1997) J . Biol. Chem. 272, 12195-12201.

40. Hall, K. T., Boumsell, L., Schultze, J. L., Boussiotis, V. A., Dorfman, D. M., Cardoso, A. A., Bensussan, A., Nadler, L. M., and Freeman, G. J . (1996) Proc. Natl. Acad. Sci. USA 93, 1178011785.

41. Dinauer, M. C., and Orkin, S. H. (1988) Immunodefic. Rev. 1, 55- 69.

42. López-Moratalla, N., Migliaccio, M., López-Zabalza, M. J ., PérezMediavilla, L. A., and Santiago, E. (1994) Biochem. Biophys. Res. Commun. 205, 2008-2012.

43. Newburger, P. E., Dai, Q., and Whitney, C. (1991). J . Biol. Chem. 266, 16171-16177.

44. Luo, W., and Skalnik, D. G. (1996) J . Biol. Chem. 271, 2344523451.

45. Yu, D., Imajoh-Ohmi, S., Akagawa, K., and Kanegasaki, S. (1996) J . Biochem. Tokyo 119, 23-28.

46. Harper, J . W., Adami, G. R., Wei, N., Keyomarsi, K., and Elledge, S. J. (1993) Cell 75, 805- 816.

47. Li, R., Waga, S., Hannon, G. J., Beach, D., and Stillman, B. (1994) Nature 371, 534-537.

48. Rouzaut, A., Subirá, M. L., De Miguel, C., Domingo-de-Miguel, E., González, A., Santiago, E., and López-Moratalla, N. (1999) Biochim. Biophys. Acta 1451, 319-333. 